\title{
RADIOGRAPHIC ALIGNMENT OF CERVICAL SPINE ON A SAMPLE OF ASYMPTOMATIC SUBJECTS
}

\author{
ALINHAMENTO RADIOGRÁFICO DA COLUNA VERTEBRAL CERVICAL \\ EM UMA AMOSTRA DE INDIVÍDUOS ASSINTOMÁTICOS

\section{ALINEACIÓN RADIOGRÁFICA DE LA COLUMNA VERTEBRAL CERVICAL EN UNA MUESTRA DE INDIVIDUOS ASINTOMÁTICOS}

\author{
Mohamed Ahmed Nasreddine', Raphael de Rezende Pratali ${ }^{1}$, Carlos Eduardo Gonçales Barsotti ${ }^{1}$, Francisco Prado Eugenio dos Santos ${ }^{1}$, \\ Carlos Eduardo Algaves Soares de Oliveira \\ 1. Hospital do Servidor Público Estadual de São Paulo (HSPE), Orthopedics and Traumatology Service, São Paulo, SP, Brazil.
}

\begin{abstract}
Objective: To present normality parameters for the cervical spine in a sample of the Brazilian population and its distribution by sex and age. Methods: This was a prospective study considering 94 asymptomatic individuals evaluated by panoramic radiograph of the spine for the analysis of the following parameters: cervical lordosis (CL), C2 sagittal vertical axis (SVA-C2), cervical sagittal vertical axis (CSVA), and T1 Slope (TA-T1). The parameter values were compared according to sex and age of individuals. Results: The mean $C L$ was $-16.5^{\circ}$ (SD: $\pm 10.8^{\circ}$ ), SVA-C2 was $-3.9 \mathrm{~mm}$ (SD: $\pm 29.2 \mathrm{~mm}$ ), cSVA was $16.9 \mathrm{~mm}$ (SD: $\pm 10.6 \mathrm{~mm}$ ) and TA-T1 was $24.8^{\circ}\left(\mathrm{SD}: \pm 7.0^{\circ}\right)$. There was no significant difference between the radiographic parameters when considered with respect to sex and age of individuals $(P>0.05)$. The analysis of correlation among the radiographic parameters showed that the TA-T1 presented the highest correlation with the other parameters, including CL $(r=0.367, P<0.01)$, SVA-C2 $(r=0.434, P<0.001)$ and CSVA $(r=0.441, P<0.001)$. There was also a correlation between SVA-C2 and cSVA ( $r=0.32, P=0.001)$ and inverse correlation between $C L$ and the cSVA $(r=-0.242, P=0.019)$. Conclusion: We introduced normality data of the cervical spine alignment in a Brazilian population sample. There was significant correlation among the analyzed parameters, especially considering TA-T1 in relation to the other parameters.
\end{abstract}

Keywords: Spine; Spinal curvatures; Radiography; Cervical vertebrae.

\section{RESUMO}

Objetivo: Apresentar os parâmetros radiográficos de normalidade para a coluna cervical em uma amostra da população brasileira, assim como sua distribuição segundo sexo e faixa etária. Métodos: Trata-se de um estudo prospectivo considerando 94 indivíduos assintomáticos avaliados por radiografia panorâmica da coluna para a análise dos seguintes parâmetros: lordose cenvical (LC), eixo vertical sagital de C2 (EVS-C2), eixo vertical sagital cervical (EVSC), ângulo de inclinação de 11 (Al-T1). Os valores dos parâmetros foram comparados quanto a sexo e faixa etária dos indivíduos. Resultados: A média da LC foi de -16,5 (DP: $\pm 10,8^{\circ}$ ), do EVS-C2 de -3,9 mm (DP: $\pm 29,2 \mathrm{~mm}$ ), do EVSC de 16,9 mm (DP: $\pm 10,6 \mathrm{~mm}$ ) e do Al-T1 de 24,8 (DP: $\left.\pm 7,0^{\circ}\right)$. Não houve diferença significante entre os parâmetros radiográficos considerados quanto a sexo e faixa etária dos indivíduos $(P>0,05)$. A análise da correlação entre os parâmetros radiográficos demonstrou que o Al-T1 apresentou a maior correlação com os demais parâmetros, incluindo LC ( $r=0,367, P<0,01)$, EVS-C2 $(r=0,434, P<0,001)$ e EVSC $(r=0,441, P<0,001)$. Houve também correlação entre EVS-C2 e EVSC $(r=0,32, P=0,001)$ e correlação inversa entre a $L C$ e o EVSC $(r=-0,242, P=0,019)$. Conclusão: Apresentamos dados de normalidade do alinhamento da coluna cenvical em uma amostra populacional brasileira. Houve correlação significante dos parâmetros analisados entre si, principalmente considerando o Al-T1 com relação aos demais parâmetros.

Descritores: Coluna vertebral; Cunvaturas da coluna vertebral; Radiografia; Vértebras cervicais.

\section{RESUMEN}

Objetivo: Presentar los parámetros radiográficos de normalidad para la columna cervical en una muestra de la población brasileña y su distribución por sexo y edad. Métodos: Se realizó un estudio prospectivo considerando 94 individuos asintomáticos evaluados por radiografía panorámica de la columna para el análisis de los siguientes parámetros: Iordosis cervical (LC), eje vertical sagital de C2 (EVS-C2), eje vertical sagital cenvical (EVSC), ángulo de inclinación de T1 (Al-T1). Los valores de los parámetros se compararon en función del sexo y la edad de Ios individuos. Resultados: El promedio de la LC fue de -16,5 (DE: $\pm 10,8^{\circ}$ ); del EVS-C2, -3,9 mm (DE: $\pm 29,2 \mathrm{~mm}$ ); del EVSC, 16,9 mm $(D E: \pm 10,6 \mathrm{~mm})$ y del $\mathrm{Al}-T 1,24,8^{\circ}\left(D E: \pm 7,0^{\circ}\right)$. No hubo diferencias significativas entre los parámetros radiográficos considerados en relación con el sexo y la edad de los individuos $(P>0,05)$. El análisis de la correlación entre los parámetros radiográficos mostró que el Al-T1 presentó la mayor correlación con los otros parámetros, incluyendo $L C(r=0,367, P<0,01)$, EVS-C2 $(r=0,434, P<0,001)$ y EVSC $(r=0,441, P<0,001)$. También hubo correlación entre EVS-C2 y EVSC ( $r=0,32, P=0,001)$ y correlación inversa entre LC y EVSC $(r=-0,242, P=0,019)$. Conclusión: Presentamos los datos de normalidad de la alineación de la columna cervical en una muestra de población brasileña. Hubo una correlación significativa de los parámetros analizados entre sí, especialmente teniendo en cuenta el Al-T1 con respecto a los demás parámetros.

Descriptores: Columna vertebral; Curvaturas de la columna vertebral; Radiografía; Vértebras cervicales. 


\section{INTRODUCTION}

The cervical region is the spinal segment with the highest mobility, in addition to being responsible for supporting the weight of the head, and it is susceptible to a series of pathologies that can significantly compromise the quality of life and cause functional disability. ${ }^{1,2}$ The cervical segment functions physiologically in lordosis and changes in this curvature are common in patients with cervical pathologies. ${ }^{2-5}$

Spinal deformity in the sagittal plane is a well-established condition, frequently associated with pain and functional disability. ${ }^{6-8}$ The correlation between loss of overall sagittal balance, represented by a plumb line dropped from C7 (Sagittal Vertical Axis), and a compromised quality of life has been demonstrated by various studies, just as better postoperative clinical outcomes have been obtained when this balance is restored. ${ }^{9-11}$ More recently, the fundamental role of the pelvis in spinal alignment has been shown, functioning as a compensation mechanism for the loss of overall sagittal balance and is also correlated with quality of life indicators. $8,12,13$

There still is a lack of information in the literature about the importance of the analysis of the radiographic parameters involving the cervical segment of the spine. Several publications have shown a correlation between deformity of the cervical spine and pain and functional disability, in addition to the intensity of the neurological deficit in patients with myelopathy. ${ }^{14-18}$ Until now, no criteria have been defined for an indication of corrective surgery for spinal deformity, nor is there any standardization of the objectives of correction of deformity. ${ }^{1}$ Recently, a classification system for cervical spine deformity was published, ${ }^{19}$ considering the type of deformity and presenting modifiers, including three radiographic parameters, in addition to the severity of the myelopathy and the SRS-Schwab classification of adult deformity types. ${ }^{20}$

However, the studies that present data about the sagittal parameters of the cervical spine, enabling the classification of cervical spine deformity, obtained the data through analyses of North American population samples. It is known that the radiographic spinopelvic anatomical parameter values are not uniform across different ethnic groups and geographical locations. ${ }^{21-24}$ Due to the lack of uniformity of these parameters, knowledge of the spinal curve patterns of a specific population is important in order for the surgeons to guide the treatment objectives for that population. This has already been done for spinopelvic parameters in a Brazilian population sample, ${ }^{25}$ but to date there is no information about radiographic normality values for the cervical spine.

The objective of this study was to present normality values for the radiographic parameters of the cervical spine in a Brazilian population sample consisting of asymptomatic volunteer subjects and their distribution by the sex and age range of the subjects in the sample.

\section{METHODS}

This is an observational prospective study, approved by the Institutional Review Board of the service responsible (opinion no. 951.141). It involved subjects older than 18 years of age, without any spine-related complaints or symptoms. After the subjects signed the Informed Consent Form (ICF), digitalized radiography examinations of the total spine (panoramic) were performed and demographic data such as sex and age were collected. Only subjects with radiographic exams extending from the base of the skull to the head of the femur bilaterally were included. Patients who did not sign the ICF and those without suitable radiographic examinations were excluded.

All the radiographs were obtained using a standard technique, with patients asked to remain standing comfortably, with the elbow in full flexion and the shoulder in $45^{\circ}$ flexion, with the hands relaxed and the fingers resting on the clavicle or the malar bone. The radiographic parameters of interest were evaluated using Surgimap Spine software (Nemaris Inc. New York, USA). Figure 1 illustrates the analysis of the radiographic parameters of the cervical spine.

The radiographic parameters considered in the study were those most often used in evaluating the alignment of the cervical spine: 1) Cervical Lordosis (CL) via the Cobb method, based on lines parallel to the lower terminal plates of $\mathrm{C} 2$ and $\mathrm{C} 7$, measured in degrees $\left(^{\circ}\right)$, being negative ("-") when lordosis is obtained and positive ("+") when kyphosis is obtained; 2) C2 Sagittal Vertical Axis (EVS-C2), the perpendicular distance between a plumb line drawn from C2 and the posterior-superior aspect of the sacrum, measured in millimeters $(\mathrm{mm})$, being considered "-" when the line falls behind the sacrum and "+" when it falls in front of the sacrum; 3) Cervical Sagittal Vertical Axis (cSVA), the perpendicular distance between a plumb line drawn $\mathrm{C} 2$ and the posterior-superior aspect of the vertebral body of $\mathrm{C} 7$, measured in millimeters ( $\mathrm{mm})$, being considered "-" when the line falls behind C7 and "+ "when it falls in front of C7; 4) T1 Tilt Angle (TA-T1), the angle between a line tangent to the upper terminal plate of $\mathrm{T} 1$ and the horizontal plane, measured in degrees $\left({ }^{\circ}\right)$.

The Kolmogorov-Smirnov test was performed to evaluate the normality of data distribution. The cervical spine radiographic parameter values were categorized by sex and by three age ranges - 18 to 39 years, 40 to 59 years, and 60 years or older, and compared using the Student's t-test and variance analysis (ANOVA), respectively. We calculated Pearson correlations between the cervical parameters analyzed, adjusted the linear regression models, and the results were illustrated using a dispersion diagram with an adjusted regression line. A significance level of $5 \%$ was used, with values of $p$ less than 0.05 being, therefore, considered statistically significant.

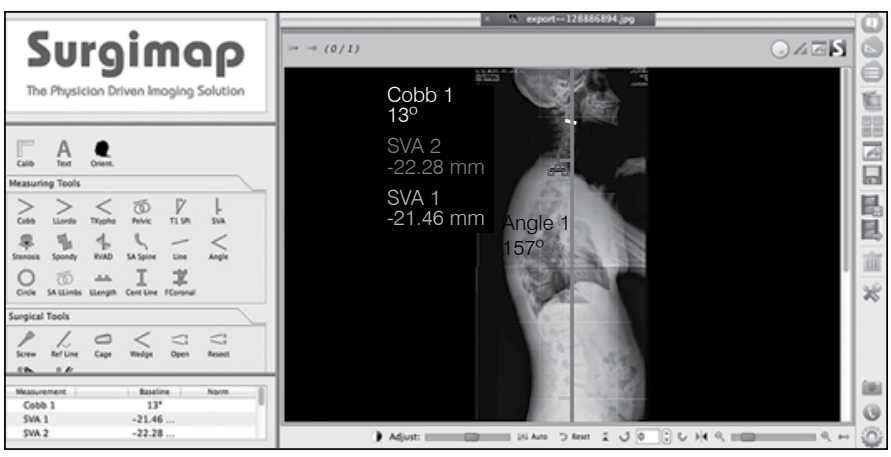

Figure 1. Measurement of the radiographic parameters of interest (CL, SVA-C2, cSVA, and TA-T1) using Surgimap Spine software (Nemaris Inc. New York, USA)

\section{RESULTS}

One hundred and ten (110) subjects agreed to participate in the study and radiographs were obtained. Of these, 16 were excluded for poor technical image quality, which made analysis of the radiographic parameters of interest impossible. Thus, the final study sample included 94 volunteers, 45 male (47.9\%) and 49 female $(52.1 \%)$. The average age of the volunteers was 41.4 years $(\mathrm{SD}=12.3$ years), ranging from 18 to 65 years. In terms of age range, 44 subjects were between 18 and 39 years of age, 45 between 40 and 59 years of age, and 5 were 60 years of age or older.

Table 1 shows the values of the radiographic parameters of interest for the full study sample. The $\mathrm{CL}$ ranged from $-1^{\circ}$ to $-44^{\circ}$, with no case presenting kyphosis of the segment between $\mathrm{C} 2$ and $\mathrm{C} 7$. The average obtained was $-16.5^{\circ}\left(\mathrm{SD}: \pm 10.8^{\circ}\right)$. The SVA-C2 ranged from $-75.4 \mathrm{~mm}$ to $73.8 \mathrm{~mm}$, averaging $-3.9 \mathrm{~mm}$ (SD: $\pm 29.2 \mathrm{~mm}$ ). The cSVA ranged from $-17.8 \mathrm{~mm}$ to $47.5 \mathrm{~mm}$, with an average value of $16.9 \mathrm{~mm}$ (SD: $\pm 10.6 \mathrm{~mm}$ ). The TA-T1 ranged from $3^{\circ}$ to $41^{\circ}$, with an average of $24.8^{\circ}\left(\mathrm{SD}: \pm 7.0^{\circ}\right)$.

Table 2 shows the values of the radiographic parameters distributed by the sex of the subjects. The average CL was $-16.4^{\circ}$ (SD: $\pm 10.4^{\circ}$ ) for the males and $-16.6^{\circ}\left(\mathrm{SD}: \pm 11.3^{\circ}\right)$ for the females, with no statistical difference between the sexes $(p=0.995)$. The average SVA-C2 was $1.6 \mathrm{~mm}$ (SD: $\pm 29.5 \mathrm{~mm}$ ) for the males and $-9.0 \mathrm{~mm}$ (SD: $\pm 28.3 \mathrm{~mm}$ ) for the females, trending towards the statistical significance $(p=0.078)$ of higher values among the male subjects. The average cSVA was $18.4 \mathrm{~mm}(\mathrm{SD}: \pm 11.0 \mathrm{~mm}$ ) for the males and $15.5 \mathrm{~mm}$ (SD: $\pm 10.2 \mathrm{~mm}$ ) for the females, with no statistical difference between the sexes $(p=0.191)$. The average TA-T1 was 
$25.7^{\circ}\left(\mathrm{SD}: \pm 7.3^{\circ}\right)$ for the males and $24.0^{\circ}\left(\mathrm{SD}: \pm 6.8^{\circ}\right.$ ) for the females, with no statistical differences in the values by sex $(P=0.240)$.

Table 3 displays the radiographic parameter values by subject age ranges. The average CL was $-15.0^{\circ}\left(\mathrm{SD}: \pm 10.6^{\circ}\right)$ in the 18 to 39 years of age group, $-18.5^{\circ}\left(\mathrm{SD}: \pm 11.3^{\circ}\right)$ in the 40 to 59 years of age group, and $-11.8^{\circ}\left(\mathrm{SD}: \pm 6.0^{\circ}\right)$ for those subjects 60 years of age or older. The average SVA-C2 was $-0.3 \mathrm{~mm}$ (SD: $\pm 31.3 \mathrm{~mm}$ ) for subjects between the ages of 18 and 39, $-9.2 \mathrm{~mm}$ (SD: \pm 26.2 $\mathrm{mm}$ ) for those between the ages of 40 and 59 , and $12.2 \mathrm{~mm}$ (SD: $\pm 30.9 \mathrm{~mm}$ ) for those 60 years of age or older. The average cSVA value was $18.1 \mathrm{~mm}(\mathrm{SD}: \pm 11.6 \mathrm{~mm}$ ) for subjects between 18 and 39 years of age, $15.7 \mathrm{~mm}$ (SD: $\pm 10.1 \mathrm{~mm}$ ) for those between 40 and 59 years of age, and $16.4 \mathrm{~mm}(\mathrm{SD}: \pm 6.5 \mathrm{~mm}$ ) for those 60 years of age and above. The average TA-T1 was $25.4^{\circ}\left(\mathrm{SD}: \pm 7.9^{\circ}\right)$ in the $18-39$ years of age group, $24.4^{\circ}\left(\mathrm{SD}: \pm 6.2^{\circ}\right.$ ) in the 40 to 59 years of age group, and $22.8^{\circ}\left(\mathrm{SD}: \pm 6.7^{\circ}\right.$ ) for those 60 and above. There was no statistically significant difference for any of the radiographic cervical spine alignment parameters in terms of age range $(P>0.05)$.

The correlation analysis between the radiographic cervical spine parameters in the sample studied (Table 4) showed that TA-T1 had the greatest correlation with the other parameters, including $\mathrm{CL}(r=0.367$, $p<0.01$, Figure 2), SVA-C2 $(r=0.434, p<0.001$, Figure 3$)$, and cSVA $(r=0.441, p<0.001)$. There was also a correlation between SVA-C2 and cSVA $(r=0.32, p=0.001)$ and an inverse correlation between CL and cSVA ( $r=-0.242, p=0.019)$.

\section{DISCUSSION}

Interest in the study of adult spinal deformity (ASD) has increased significantly in the past few years, motivated by the changing demographics observed in most countries as the elderly population grows. A recent study reported that up to $60 \%$ of the population over 60 years of age may present some degree of spinal deformity. ${ }^{26}$ Although some individuals with ASD are completely asymptomatic, others experience pain and significant functional disability, and the correlation between the quality of life and the radiographic parameters of ASD is consistently demonstrated. ${ }^{6-10}$ In this context, spinal alignment has played a progressively critical role in the evaluation of ASD. ${ }^{1,14-16}$

Table 1. Values of the radiographic parameters of interest in the total study sample.

\begin{tabular}{c|c|c|c|c}
\hline \multirow{2}{*}{ Variable } & \multirow{2}{*}{ Average } & \multirow{2}{*}{ SD } & \multicolumn{2}{|c}{ Cl (95\%) } \\
\cline { 4 - 5 } & & & Inferior & Superior \\
\hline CL (degrees) & 16.5 & 10.8 & 14.3 & 18.7 \\
\hline SVA-C2 $(\mathrm{mm})$ & -3.9 & 29.2 & -9.8 & 2.0 \\
\hline $\begin{array}{c}\text { TA-T1 } \\
\text { (degrees) }\end{array}$ & 24.8 & 7.0 & 23.4 & 26.2 \\
\hline CSVA $(\mathrm{mm})$ & 16.9 & 10.6 & 14.7 & 19.0 \\
\hline
\end{tabular}

Total of 94 cases; Cl: confidence interval; $\mathrm{Nl}$ : normality interval

Table 2. Values of the radiographic parameters distributed by sex.

\begin{tabular}{c|c|c|c|c|c}
\hline \multirow{2}{*}{ Variable } & \multicolumn{2}{|c|}{ Male (N= 45) } & \multicolumn{2}{c|}{ Female (N= 49) } & \multirow{2}{*}{$\mathbf{p}$} \\
\cline { 2 - 5 } & Average & SD & Average & SD & \\
\hline CL (degrees) & 16.4 & 10.4 & 16.6 & 11.3 & 0.955 \\
\hline SVA-C2 (mm) & 1.6 & 29.5 & -9 & 28.3 & 0.078 \\
\hline TA-T1 (degrees) & 25.7 & 7.3 & 24 & 6.8 & 0.240 \\
\hline CSVA(mm) & 18.4 & 11 & 15.5 & 10.2 & 0.191 \\
\hline
\end{tabular}

Student's t-test.

Table 3. Values of the radiographic parameters distributed by age range.

\begin{tabular}{c|c|c|c|c|c|c|c}
\hline \multirow{2}{*}{ Variable } & \multicolumn{2}{|c|}{\begin{tabular}{c}
$\mathbf{4 8}$ to $\mathbf{4 9}$ (N) \\
\cline { 2 - 7 }
\end{tabular}} & $\begin{array}{c}\mathbf{4 0} \text { to } \mathbf{5 9} \mathbf{( N =} \\
\mathbf{4 5})\end{array}$ & \multicolumn{2}{|c|}{$\begin{array}{c}\mathbf{6 0} \text { or older } \\
\mathbf{( N =} \mathbf{5})\end{array}$} & \multirow{2}{*}{$\mathbf{p}$} \\
& Average & SD & Average & SD & Average & SD & \\
\hline CL (degrees) & 15 & 10.6 & 18.5 & 11.3 & 11.8 & 6.0 & 0.197 \\
\hline SVA-C2 (mm) & -0.3 & 31.3 & -9.2 & 26.2 & 12.2 & 30.9 & 0.162 \\
\hline TA-T1 (degrees) & 25.4 & 7.9 & 24.4 & 6.2 & 22.8 & 6.7 & 0.653 \\
\hline CSVA(mm) & 18.1 & 11.6 & 15.7 & 10.1 & 16.4 & 6.5 & 0.577 \\
\hline
\end{tabular}

Table 4. Analysis of the correlation between the radiographic parameters of the cervical spine in the study sample.

\begin{tabular}{c|c|c|c|c}
\hline \multicolumn{2}{c|}{ Correlation } & TA-T1 & $\begin{array}{c}\text { Cervical } \\
\text { lordosis }\end{array}$ & SVA-C2 \\
\hline \multirow{2}{*}{ Cervical Lordosis } & $\mathrm{r}$ & 0.367 & & \\
\cline { 2 - 5 } & $\mathrm{p}$ & $<0.001$ & & \\
\hline \multirow{2}{*}{ SVA-C2 } & $\mathrm{r}$ & 0.434 & -0.038 & \\
\cline { 2 - 5 } & $\mathrm{p}$ & $<0.001$ & 0.717 & \\
\hline \multirow{2}{*}{ CSVA(mm) } & $\mathrm{r}$ & 0.441 & -0.242 & 0.35 \\
\cline { 2 - 5 } & $\mathrm{p}$ & $<0.001$ & 0.019 & 0.001 \\
\hline
\end{tabular}

Pearson. Correlation

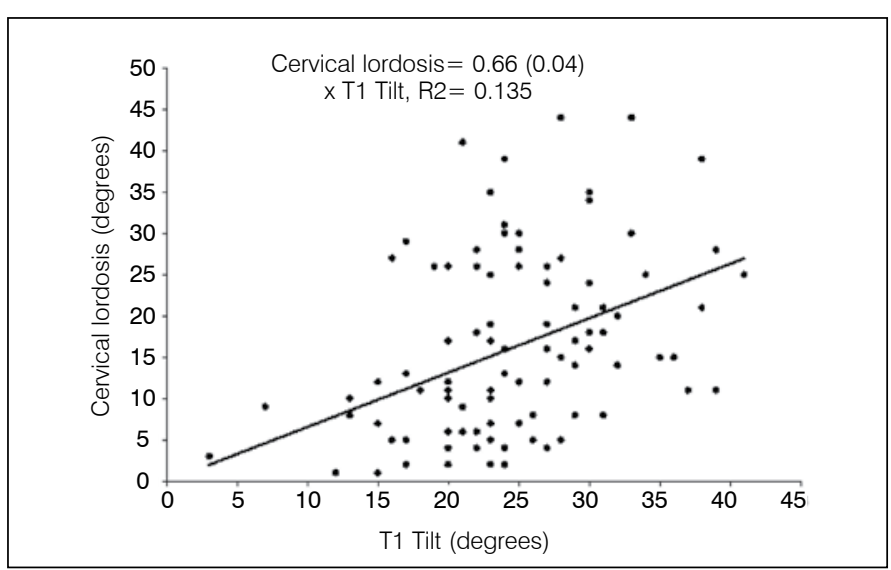

Figure 2. Diagram of the dispersion between Cervical lordosis and the T1 Tilt angle and regression line adjustment.

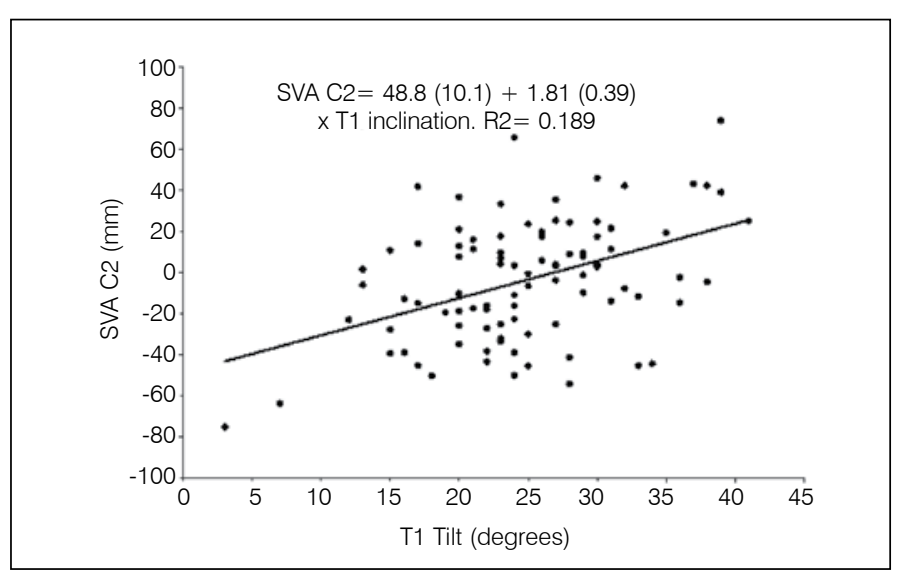

Figure 3. Diagram of the dispersion between Cervical lordosis and the Sagittal vertical axis of $\mathrm{C} 2$ and regression line adjustment.

Because the segments of the spine are not mutually independent, the alignment of the cervical spine depends on the degree of both thoracic kyphosis and lumbar lordosis, adapting itself to the other curvatures of the spine. ${ }^{1}$

The definition of normal values for the radiographic parameters is important for understanding the extent of the ASD, as well as for establishing the objectives for sagittal realignment spine surgery. As for the cervical spine, few studies present normality values, all of which deal exclusively with a specific North American population, and no data is available for our Brazilian population.

In our study, we analyzed the sagittal alignment parameters of the cervical spine in a sample Brazilian population of adult asymptomatic subjects with the goal of defining normality values in our environment. Hardacker et al. ${ }^{5}$ published a study of 100 individuals between the ages of 20 and 70 without symptoms involving the cervical spine. The average $\mathrm{CL}$ of the total sample was $-40.0^{\circ}\left(\mathrm{SD}: \pm 9.7^{\circ}\right.$ ), while that obtained in our study was $-16.5^{\circ}$ (SD: $\pm 10.8^{\circ}$ ). However, in the study by Hardacker et al., ${ }^{5}$ the $\mathrm{Cl}$ was measured from the occipital bone to 
$\mathrm{C} 7$, while ours considered the angle between $\mathrm{C} 2$ and $\mathrm{C} 7$. It is known that most cervical lordosis (75-80\%) occurs because of the C1-C2 segment, ${ }^{2,5}$ excluded from this study, which could explain the lower average $C L$ value as compared to the previously published study.

In the study by Hardacker et al. ${ }^{5}$ there was no difference in the total CL between the men and women $(p=0.4)$, just as there was no difference in the $C L$ between the sexes in our sample $(p=0.995)$. In terms of age, the Hardacker et al. study ${ }^{5}$ showed that with increasing age, divided into decades, the CL was accentuated, something we did not observe in our study sample, in which there was no difference in $C L$ among the three age ranges considered $(p=0.197)$. More recently, a study analyzed a population of 55 asymptomatic individuals in which a significant difference was observed in the CL and the TA-T1 values divided into age ranges of 20-39, 40-59, and 60 years of age or older $\left(p<0.01\right.$ and $=0.01$, respectively ). ${ }^{2}$ However, the sample in our study had only five asymptomatic patients 60 years of age or older, and studies with a greater number of volunteers, making the age range groups more homogenous, can better determine the existence of a correlation between age and cervical parameters.

This study also showed a statistically significant correlation between the radiographic cervical spine parameters analyzed, particularly between TA-T1 and the other parameters. In their study of 113 patients who underwent posterior approach arthrodesis of the cervical spine, Tang et al. ${ }^{15}$ found a significant correlation between
C1-C7 SVA and C1-C2 lordosis $(r=0.28, p=0.002)$, between C2C7 SVA and C1-C2 lordosis $(r=0.33, p=0.001)$, and between the center of gravity of the head-C7 SVA and C1-C2 lordosis $(r=0.22$, $p=0.02)$. The authors also stated that there was no other significant correlation between any of the other parameters.

The identification of a significant correlation between the cervical parameters, observed primarily in relation to TA-T1, reinforces the concept that these parameters are not mutually exclusive, being interconnected in order to cross-check the spatial orientation of the cervical spinal segment. The important role of $\mathrm{T} 1$ in determining the alignment of the cervical spine segment was clear, much like that of the sacrum on the alignment of the lumbar spine.

\section{CONCLUSION}

We present data about normal cervical spine alignment parameters in a Brazilian population sample. There was no difference between the parameters in terms of the sex or the age group of the subjects. There was significant correlation between the parameters analyzed, especially in considering the T1 Tilt Angle with the other parameters.

All the authors declare that there are no potential conflicts of interest regarding this article.

CONTRIBUTIONS OF THE AUTHORS: Each author made significant individual contributions to the development of this manuscript. Study concept and design: RRP. Data collection and IRB approval: MAN. Data analysis and interpretation: RRP and MAN. Article development: MAN. Critical review of the article: RRP. Review of the final version for submission: RRP, MAN, CEGB, FPES e CEASO.

\section{REFERENCES}

1. Scheer JK, Tang JA, Smith JS, Acosta FL Jr, Protopsaltis TS, Blondel B, et al. Cervical spine alignment, sagittal deformity, and clinical implications: a review. J Neurosurg Spine. 2013;19(2):141-59.

2. Ames CP, Blondel B, Scheer JK, Schwab FJ, Le Huec JC, Massicotte EM, et al. Cervical radiographical alignment: comprehensive assessment techniques and potential importance in cervical myelopathy. Spine (Phila Pa 1976). 2013;38(22 Suppl 1):S149-60

3. Gay RE. The curve of the cervical spine: variations and significance. J Manipulative Physiol Ther. 1993;16(9):591-4.

4. McAviney J, Schulz D, Bock R, Harrison DE, Holland B. Determining the relationship between cervical lordosis and neck complaints. J Manipulative PhysiolTher. 2005:28(3):187-93

5. Hardacker JW, Shuford RF, Capicotto PN, Pryor PW. Radiographic standing cervical segmental alignment in adult volunteers without neck symptoms. Spine (Phila Pa 1976). 1997;22(13):1472-80.

6. Fu KM, Smith JS, Sansur CA, Shaffrey Cl. Standardized measures of health status and disability and the decision to pursue operative treatment in elderly patients with degenerative scoliosis. Neurosurgery. 2010;66(1):42-7.

7. Smith JS, Shaffrey Cl, Berven S, Glassman S, Hamill C, Horton W, et al. Improvement of back pain with operative and nonoperative treatment in adults with scoliosis. Neurosurgery. 2009:65(1):86-93

8. Ames CP, Smith JS, Scheer JK, Bess S, Bederman SS, Deviren V, et al. Impact of spinopelvic alignment on decision making in deformity surgery in adults: A review. J Neurosurg Spine. 2012;16(6):547-64

9. Smith JS, Shaffrey Cl, Fu KM, Scheer JK, Bess S, Lafage V, et al. Clinical and radiographic evaluation of the adult spinal deformity patient. Neurosurg Clin N Am. 2013;24(2):143-56.

10. Glassman SD, Bridwell K, Dimar JR, Horton W, Berven S, Schwab F. The impact of positive sagittal balance in adult spinal deformity. Spine (Phila Pa 1976). 2005;30(18):2024-9.

11. Smith JS, Lafage V, Schwab FJ, Shaffrey Cl, Protopsaltis T, Klineberg E, et al. Prevalence and type of cervical deformity among 470 adults with thoracolumbar deformity. Spine (Phila Pa 1976). 2014:39(17):E1001-9.

12. Lafage V, Schwab F, Patel A, Hawkinson N, Farcy JP. Pelvic tilt and truncal inclination: two key radiographic parameters in the setting of adults with spinal deformity. Spine (Phila $\mathrm{Pa}$ 1976). 2009;34(17):E599-606.

13. Schwab F, Lafage V, Patel A, Farcy JP. Sagittal plane considerations and the pelvis in the adult patient. Spine (Phila Pa 1976). 2009;34(17):1828-33.

14. Villavicencio AT, Babuska JM, Ashton A, Busch E, Roeca C, Nelson EL, et al. Prospective, randomized, double-blind clinical study evaluating the correlation of clinical outcomes and cervical sagittal alignment. Neurosurgery. 2011;68(5):1309-16.
15. Tang JA, Scheer JK, Smith JS, Deviren V, Bess S, Hart RA, et al. The impact of standing regional cervical sagittal alignment on outcomes in posterior cervical fusion surgery. Neurosurgery. 2012;71(3):662-9.

16. Ames CP, Blondel B, Scheer JK, Schwab FJ, Le Huec JC, Massicotte EM, et al. Cervical radiographical alignment: comprehensive assessment techniques and potential importance in cervical myelopathy. Spine (Phila Pa 1976). 2013;38(22 Suppl 1):S149-60.

17. Smith JS, Lafage V, Ryan DJ, Shaffrey Cl, Schwab FJ, Patel AA, et al. Association of myelopathy scores with cervical sagittal balance and normalized spinal cord volume: analysis of 56 preoperative cases from the AOSpine North America Myelopathy study. Spine (Phila Pa 1976). 2013;38(22 Suppl 1):S161-70.

18. Grosso MJ, Hwang R, Mroz T, Benzel E, Steinmetz MP. Relationship between degree of focal kyphosis correction and neurological outcomes for patients undergoing cervical deformity correction surgery. J Neurosurg Spine. 2013:18(6):537-44

19. Ames CP, Smith JS, Eastlack R, Blaskiewicz DJ, Shaffrey Cl, Schwab F, et al. Reliability assessment of a novel cervical spine deformity classification system. J Neurosurg Spine. 2015;23(6):673-83

20. Sengupta DK. Schwab F Ungar B, Blondel B, et al. Scoliosis research society-Schwab adult spinal deformity classification-a validation study. Spine 2012;37:1077-82.

21. Vialle R, Levassor N, Rillardon L, Templier A, Skalli W, Guigui P. Radiographic analysis of the sagittal alignment and balance of the spine in asymptomatic subjects. J Bone Joint Surg Am. 2005:87(2):260-7.

22. Mac-Thiong JM, Roussouly P, Berthonnaud E, Guigui P. Sagittal parameters of global spinal balance: normative values from a prospective cohort of seven hundred nine Caucasian asymptomatic adults. Spine (Phila Pa 1976). 2010;35(22):E1193-8.

23. Lee CS, Chung SS, Kang KC, Park SJ, Shin SK. Normal patterns of sagittal alignment of the spine in young adults radiological analysis in a Korean population. Spine (Phila Pa 1976). 2011;36(25):E1648-54.

24. Zárate-Kalfópulos B, Romero-Vargas S, Otero-Cámara E, Correa VC, Reyes-Sánchez A. Differences in pelvic parameters among Mexican, Caucasian, and Asian populations. J Neurosurg Spine. 2012;16(5):516-9.

25. Pratali RR, Luz CO, Barsotti CEG, Santos FPE, Oliveira CEA. Análise dos parâmetros do equilíbrio sagital e espino-pélvico em uma amostra populacional brasileira. Coluna/ Columna. 2014:13(2):108-11

26. Schwab F, Dubey A, Gamez L, El Fegoun AB, Hwang K, Pagala M, Farcy JP. Adult scoliosis: prevalence, SF-36, and nutritional parameters in an elderly volunteer population. Spine (Phila Pa 1976). 2005;30(9):1082-5 